University for Business and Technology in Kosovo

UBT Knowledge Center

Nov 2nd, 9:00 AM - Nov 3rd, 5:00 PM

\title{
Systems Engineering and Project Management in Architectural design and Construction at Postwar Countries
}

\author{
Lulzim Beqiri \\ University for Business and Technology, lulzimbeqiri@gmail.com
}

Follow this and additional works at: https://knowledgecenter.ubt-uni.net/conference

Part of the Architecture Commons

\section{Recommended Citation}

Beqiri, Lulzim, "Systems Engineering and Project Management in Architectural design and Construction at Postwar Countries" (2012). UBT International Conference. 25.

https://knowledgecenter.ubt-uni.net/conference/2012/all-events/25

This Event is brought to you for free and open access by the Publication and Journals at UBT Knowledge Center. It has been accepted for inclusion in UBT International Conference by an authorized administrator of UBT Knowledge Center. For more information, please contact knowledge.center@ubt-uni.net. 


\title{
Systems Engineering and Project Management in Architectural design and construction at post war countries. \\ Case Study- Centre for Artificial Insemination in Arbanë (Vitomirice) Peja Region. R. of Kosova
}

\author{
Lulzim Beqiri, PhD Candidate ${ }^{1}$ \\ Vienna University of Technology, Vienna; Austria \\ ${ }^{I}$ University for Business and Technology, Faculty of Architecture and Spatial Planning \\ lbeqiri@ubt-uni.net; lulzimbeqiri@gmail.com
}

\begin{abstract}
This paper presents the relation and involvement of project management and systems engineering in construction projects implemented in post was countries.

The process of design, construction and investment in creating an architectural structure in Kosova hasn't applied elements of systems engineering.

The design and construction from the investor's perspective are yet being developed individually. This paper aims to bring the model of project management and systems engineering based on case study experience in order to introduce the modern approach to the design and construction and facilitate the implementation of any construction project.

Furthermore this model was designed based on best practice presented through recent edited books and papers in the field of Systems engineering and Project management.

The model presents the initiative for design and construction process in Kosova toward system thinking and systems approach that will generate values in construction industry in Kosova. This model could also be applicable in the post war transitional countries considering that this case study identifies gaps in the project management and as such assists in building modelling and construction.
\end{abstract}

Key words: project management, systems engineering, design, construction 